\title{
Variables Influencing Provincial Government's Role to Manage the Interface between Environmental Protection and Economic Development: Considerations to Improve Sustainable Development in South Africa
}

\author{
Christelle J. Auriacombe \\ (Corresponding Author) \\ School of Pubic Management, Governance and Public Policy, University of Johannesburg \\ christellea@uj.ac.za

\section{Shikha Vyas-Doorgapersad} \\ School of Public Management, Governance and Public Policy, \\ University of Johannesburg, South Africa \\ svyas-doorgapersad@uj.ac.za \\ DOI//http://dx.doi.org/10.4314/gjds.v16i2.1
}

\begin{abstract}
The article aims to highlight the nature, content and scope of continental and subnational sustainability priorities, with reference to specific perspectives of environmental and economic development, agriculture, food security, energy, health, water and sanitation. As such, subnational governments need to devise sustainable strategies to manage these demands in an efficient manner. As a methodological approach, the authors conducted a desktop analysis of applicable literature and official documents to conceptualise and contextualise the area of investigation. The data collection sources for the desktop analysis included global authoritative books, articles, as well as regulatory, policy and strategy documents in South African context. The methodological approach included unobtrusive research techniques. When studying social behaviour, unobtrusive research techniques encourage contextual and conceptual analysis, while helping to remove bias. Research results highlight the challenging nature of designing and implementing environmental programmes, policies and strategies in South Africa. This is due to inadequate human capacity, chronic resource shortages and inadequate intergovernmental coordination,
\end{abstract}


while the respective responsibilities of national, provincial and local authorities are not clearly outlined. Further challenges include insufficient political will and environmentally sustainable leadership to support the environmental agenda.

Keywords: Economic Development, Environmental Protection, Sustainable Development, Sustainability, Natural Resource Management

\section{BACKGROUND AND INTRODUCTION}

Until recently, the environment was regarded as extrinsic to humanity's well-being. It was mostly used and exploited at will, while special areas were demarcated for wildlife conservation. Challenges relating to the environment and nature were mostly seen as local problems that could be overcome with human knowledge, technology and natural resource management (Chasek \& Wagner, 2012). Economic growth dominated the issue of human relationships, while higher production rates were seen as the best avenue to promote well-being (Castro, 2004:195). However, it has to be realised that "the Earth has a finite supply of natural resources. A shift towards sustainable development has become imperative as concerns for the environment and its ability to maintain current consumption rates continue to grow" (Haque, 1999). With the looming threat of climate change, countries throughout the world are focusing on sustainable development (Saunders, 2014).

The emphasis on sustainable development is based on an increased focus on global interventions to overcome socio-economic and environmental challenges. There are several interpretations of the terms 'sustainability' and 'sustainable development'. Saunders (2014:220-232) argues that, in the international arena, sustainable development is viewed as a conceptual development framework that highlights interdependent links between "economic growth, social equity and environmental integrity".

The research objectives of this article include, inter alia, to contextualise and conceptualise environmental and economic development perspectives, explore agriculture and food security perspectives, consider energy perspectives and outline water, sanitation, access to basic services and health perspectives in terms of global and continental sustainable initiatives.

\section{GLOBAL, NATIONAL AND SUBNATIONAL HISTORICAL AND REGULATORY CONTEXT}

The 1992 United Nations Conference on Environment and Development (UNCED), commonly known as the Rio Earth Summit or Rio 1992, led to the establishment 
of a comprehensive action plan to facilitate global, national, provincial and local sustainable development (Castro, 2004:196 and United Nations, 1992a). Known as Agenda 21, the action plan focuses on issues that should be on the $21^{\text {st }}$ century global agenda. Section 11 of the extensive 300-page document deals with 'Conservation and Management of Resources for Development', which includes protecting the atmosphere, countering deforestation, protecting delicate environments, preserving biodiversity, controlling pollution, as well as managing biotechnology and radioactive wastes (Auriacombe \& Jarbandhan, 2015:119; Van der Waldt \& Auriacombe, 2014; Castro, 2004:196 and Lele, 1991:610).

Although South Africa was not an official participant at the Rio Earth Summit, a country report titled 'Building the foundation for sustainable development in South Africa' was prepared to outline the status of the country's natural environment (Auriacombe \& Jarbandhan, 2015:120; Van der Waldt \& Auriacombe, 2014). Responses to sustainable development-related challenges and an action-based agenda were also included. In early-1996, a follow-up document was published that outlined the status and management of South Africa's environment (Van der Waldt \& Auriacombe, 2014).

Following the Rio Earth Summit, the Commission on Sustainable Development (CSD) was formed (United Nations, 1992). This high-level international forum on sustainable development underscores government, civil society, business and industry as key stakeholders. To this end, member countries are required to hand in regular progress reports to the CSD (UN, 1992 and Van der Waldt \& Auriacombe, 2014). The CSD's third session in April 1995 saw South Africa participating officially for the first time. In South Africa's case, the Department of Environmental Affairs (DEA) (formerly known as the Department of Environmental Affairs and Tourism), the Department of International Relations and Cooperation (DIRCO) (formerly known as the Department of Foreign Affairs), the Department of Trade and Industry (dti), the Department of Mineral Resources (DMR) (formerly known as the Department of Minerals and Energy), the Department of Energy (DoE) and the Department of Science and Technology (DST) submit highlights to the 'South African Country Report', which outlines the country's progress. Providing a profile of South Africa's response to climate change is one of the country's key CSD-related environmental objectives (Van der Waldt \& Auriacombe, 2014 and Auriacombe \& Jarbandhan, 2015:1120).

In 1996, South Africa sent a considerably larger delegation to the fourth session of the CSD (Auriacombe \& Jarbandhan, 2015:121). With its greater representation of national departments, the country demonstrated a strong commitment to participating in CSD meetings (Auriacombe \& Jarbandhan, 2015:121). Since UNCED, 
the South African Government has ratified the Basel Convention in May 1994, as well as the Convention on Biological Diversity in September 1995. Furthermore, the country signed the Convention on Desertification, the Framework Convention on Climate Change and the World Heritage Convention (Auriacombe \& Jarbandhan, 2015:121; Van der Waldt \& Auriacombe, 2014).

Established in 1997, the CSD spearheaded various Agenda 21-related initiatives in South Africa. In this regard, the United Nations Development Programme (UNDP) was approached to support South Africa through the UNDP Capacity 21 Programme (Auriacombe \& Jarbandhan, 2015:121). With the assistance of the International Council for Local Environmental Initiatives (ICLEI) and the United States Agency for International Development (USAID), the former Department of Environmental Affairs and Tourism organised an African Regional Seminar in 1995. With the theme 'Towards Urban Reconstruction and Development', the seminar mainly focused on non-African and African countries' implementation of local Agenda 21 initiatives (Auriacombe \& Jarbandhan, 2015:122; Van der Waldt \& Auriacombe, 2014).

The Millennium Declaration that was signed by 189 countries in September 2000 , as well as subsequent discussions by member states at the 2005 World Summit, gave rise to eight developmental priorities, known as the Millennium Development Goals (MDGs) (Sachs, 2012:2206-2211 and Van der Waldt \& Auriacombe, 2014). These goals and targets were interrelated and interdependent. Goal 7, for example, was to ensure environmental sustainability and should thus be seen as an integrated whole. The idea was that all countries be partners in facilitating development and eliminating poverty. As a UN member state, South Africa was a signatory to this agreement. Each year during the annual State of the Nation Address (SONA), the President was expected to provide an update on the implementation of the former MDGs (Auriacombe \& Jarbandhan, 2015:122; Van der Waldt \& Auriacombe, 2014).

World leaders adopted the 2030 Agenda for Sustainable Development at the UN Sustainable Development Summit on 25 September 2015 (UN Habitat, 2012) as a follow-up to the 15-year MDG period (United Nations Economic Commission for Africa (UNECA), 2015). According to the report, 'Roadmap for Localising the SDGs: Implementation and Monitoring at Subnational Level' (UN Habitat, 2012), a set of 17 Sustainable Development Goals (SDGs) were developed to "to end poverty, fight inequality and injustice, and tackle climate change by 2030". The report defines localising SDGs as "a process of taking into account subnational contexts in the achievement of the 2030 Agenda, from the setting of goals and targets, to determining the means of implementation and using indicators to measure and monitor progress" (UN Habitat, 2012). The report adds that subnational governments "can support the achievement of the SDGs through action from the 
bottom up and on how the SDGs can provide a framework for local development policy...the achievement of the SDGs depends, more than ever, on the ability of local and regional governments to promote integrated, inclusive and sustainable territorial development...many of the investments to achieve the SDG goals will take place at the subnational level" (UN Habitat, 2012).

For a number of African countries, attention has been directed at investigating the impact of structural adjustment initiatives on the environment. The International Monetary Fund (IMF) and the World Bank in particular supported structural adjustment programmes, as certain government policies had a negative impact on the environment (Cavalcanti, 2000:87). The New Partnership for Africa's Development (NEPAD) aimed to create a partnership to address the challenges that Africans face. "The principles that underpin this partnership are that development is a process of empowerment and self-reliance" (NEPAD, 2001 in Auriacombe \& Jarbandhan, 2015:123). NEPAD is a platform for African countries to interact with the rest of the world, including industrialised countries and multilateral organisations. Created by Africans for Africans, the NEPAD agenda is one where people shape their own destinies through their own initiatives and of their own volition. To facilitate sustainable development and reduce poverty levels, Africa needs to create the capacity to maintain the required growth rate. "This, in turn, depends on factors such as infrastructure, capital accumulation, human capital, institutions, structural diversification, competitiveness, health, and good stewardship of the environment through environmental protection programmes" (NEPAD, 2001 Auriacombe \& Jarbandhan, 2015:123).

The Constitution of the Republic of South Africa, 1996, highlights that the state must protect, respect and fulfil citizens' rights, as enshrined in the Bill of Rights. Section 24 on the environment indicates that everyone has the right:

a) to an environment that is not harmful to their health and well-being;

b) to have the environment protected for the benefit of present and future generations through reasonable legislative; and other measures that:

(i) prevent pollution and ecological degradation;

(ii) promote conservation; and

(iii) secure ecologically sustainable development and the use of natural resources while promoting justifiable economic and social development" (The Constitution of the Republic of South Africa, 1996).

The White Paper on Local Government, 1998, translates the objectives of Sections 152 and 153 of the Constitution into the term 'developmental local government'. In the White Paper, 'developmental local government' is contextualised as a dedicated 
local government that works alongside citizens and community groups to find sustainable solutions to socio-economic challenges and ensure a better quality of life (Auriacombe \& Jarbandhan, 2015:124).

The National Environment Management Act 107 of 1998 (NEMA) established participatory, cooperative and developmental governance in environmental management. This law has been amended several times to ensure that the environment is regulated more stringently (DEA Strategic Plan 2009-2014 in Auriacombe \& Jarbandhan, 2015:124). The Mineral and Petroleum Resources Development Act 28 of 2002 also effectively nationalised mineral assets and led to the Mining Charter of 2004.

In 2002, South Africa hosted the World Summit on Sustainable Development, where it became clear that the global commitment to sustainable development needed to be reinforced. As such, the summit delivered a number of key outcomes such as the Johannesburg Plan of Implementation (JPOI) of 2002 and several partnership initiatives. A declaration with a political underpinning, JPOI (2002) requires that, "States should take immediate steps to make progress in the formulation and elaboration of national strategies for sustainable development and begin their implementation by 2005". After the World Summit, Cabinet mandated the former Departments of Environmental Affairs and Tourism and Foreign Affairs to draft a National Strategy for Sustainable Development (Auriacombe \& Jarbandhan, 2015:124 and Van der Waldt \& Auriacombe, 2014).

The National Framework for Sustainable Development (NFSD) of 2008 is a forwardlooking strategy that promotes the effective stewardship of natural, social and economic resources. As a long-term commitment to sustainable development, the NFSD aligns environmental protection, social equity and economic efficiency with the country's values and vision. Furthermore, it defines country-focused sustainable development principles, while considering global challenges and growth principles (Van der Waldt \& Auriacombe, 2014).

The NFSD is divided into the following three phases:

- Phase one (2003-2008): Long-term socio-economic and environmental trends were analysed and related policy initiatives were undertaken. These steps informed the vision, goals and strategic priorities of sustainable development, which culminated in the NFSD, as adopted by the Cabinet in June 2008 (Van der Waldt \& Auriacombe, 2014).

- Phase two (2009-2010): A strategy and action plan for 2010-2014 was drafted to help implement the NFSD's vision, goals and strategic priorities. It included proposals for implementing institutional and monitoring and 
evaluation (M\&E) frameworks to drive sustainable development and trace the implementation of NFSD, respectively (Van der Waldt \& Auriacombe, 2014).

- Phase three (2011-2014 and 2015-2020): While several activities have been implemented, the formal action plan will commence upon its approval. After implementation, continuous M\&E will track progress towards a sustainable society and provide feedback to create an adaptive management system (DEA, 2011).

The goals of the NFSD are:

- “To develop and promote new social and economic goals based on ecological sustainability and build a culture that recognises that socio-economic systems are dependent on and embedded within ecosystems;

- To increase awareness and understanding of the value of ecosystem services to human well-being;

- To ensure effective integration of sustainability concerns into all policies, planning and decision-making at national, provincial and local levels;

- To ensure effective integration and collaboration across all functions and sectors; and

- To monitor, evaluate and report performance and progress in respect of ecological sustainability" (DEA, 2011).

The strategy is based on five strategic principles, namely to bolster integrated planning and implementation systems; sustain ecosystems and use natural resources effectively; take strides 'towards a green economy'; build sustainable communities; and find effective response mechanisms for climate change. The strategic priority, 'towards a green economy' (Auriacombe, 2014), focuses on transitioning towards a resource-efficient, low-carbon and employment-centered growth trajectory. This objective aims to support regulatory frameworks and interventions such as the National Green Economy Strategy and Green Economy Implementation Plans (Green Economy Implementation Plans, 2010). Government's response to rapid climate change is outlined in the National Climate Change Response White Paper of 2011. Notably, this White Paper aims to provide "effective climate change response and the long-term, just transition to a climate-resilient and lower carbon economy and society", while making an effort to stabilise greenhouse gas (GHG) emissions (The National Climate Change Response White Paper of 2011). Furthermore, the Integrated Resource Plan of 2010 (IRP) focuses on determining the country's long-term electricity requirements (Auriacombe \& Jarbandhan, 2015:124). Based on its current trajectory, the IRP estimates that by 2030, renewable sources 
will constitute $17800 \mathrm{MW}$ (42\%) of the country's energy generation (Auriacombe, 2014).

The Medium-Term Strategic Framework (MTSF) 2009-2014 (in National Planning Commission (NPC) 2009) is government's statement of intent in terms of its economic vision and future development. It identifies development challenges that South Africa faces and provides a medium-term strategy to improve citizens' living conditions (NPC, 2009).

When developing their five-year strategic plans and budget requirements, national and provincial departments in particular need to consider mediumterm imperatives. Similarly, informed by the MTSF and their 2006 mandates, municipalities are expected to align their integrated development plans (IDPs) with national medium-term priorities.

Linked to its five over-arching objectives, the MTSF (in Auriacombe, 2014:122) outlines ten priority areas to give effect to these strategic objectives:

- Strategic Priority One: Speeding up growth and transforming the economy to create decent work and sustainable livelihoods.

- Strategic Priority Two: Implementing a large-scale programme to build economic and social infrastructure.

- Strategic Priority Three: Creating a comprehensive rural development strategy that is linked to food security, as well as land and agrarian reform.

- Strategic Priority Four: Strengthening the country's skills and human resource base.

- Strategic Priority Five: Improve the health status of all citizens.

- Strategic Priority Six: Upscale the fight against crime and corruption.

- Strategic Priority Seven: Create sustainable, cohesive and caring communities.

- Strategic Priority Eight: Helping to advance the African continent and bolster international cooperation.

- Strategic Priority Nine: A focus on sustainable resource usage and management.

- Strategic Priority Ten: Building a developmental state, which includes improving public services and strengthening democratic institutions.

This framework aims to create and implement an all-inclusive development strategy that will meet the needs of all South Africans. The MTSF also mandates government and its development partners to commit to a gender equality programme that 
creates the right conditions "for the full participation of women in all critical areas of human endeavour" (Auriacombe, 2014:122).

Under former Minister Trevor Manuel, the NPC produced a second policy document - the National Development Plan (NDP) of 2011. The NDP, which was officially launched on 19 February 2011, offers a long-term sustainable development perspective, defines a desired destination and outlines different sectors of society's role in eradicating poverty and reducing inequality by 2030 (NPC, 2011). Also known as Vision 2030, the NDP highlights that these goals can be realised by drawing on the collective knowledge and energy of citizens, building an inclusive economy, enhancing capabilities, growing the state's capacity, as well as supporting leadership and partnerships throughout society (NPC, 2011). Led by the President and Cabinet, all South Africans should have a vested interest in realising the plan.

As a broad-based strategic framework, Vision 2030 serves as a guideline to make important decisions and take action. The NDP emphasises the following key policy and strategic directions (threads) (NPC, 2011):

- A developmental policy thread: Supports the notions of a developmental state and environmental protection (natural resources as economic commodities)

- An economic growth policy thread: Focuses on the first economy.

- An interventionist policy thread: Government interventions in the economy to garner private sector and business support, so that developmental goals are met.

The NDP presents a long-term outlook on socio-economic development and outlines the role that various sectors in society should play to help reach these goals. The goal of Vision 2030 is to ensure that all South Africans enjoy a decent standard of living by eliminating poverty and reducing inequality. The NDP (2011) highlights access to housing, water, electricity, sanitation, safe and reliable public transport, quality education and skills development, safety and security; quality healthcare, social protection, employment opportunities, recreation and leisure, a clean environment and adequate nutrition as core components of a decent standard of living.

Vast energy resources are needed to facilitate the country's growth path. Notably, 98\% of government's energy is generated from non-renewable sources, while renewable energy only constitutes $2 \%$ (Auriacombe \& Jarbandhan, 2015:125). Based on the aforementioned state of affairs, the DEA adopted its Strategic Plan for the Environmental Sector, 2009-2014. Notably, the plan aimed to promote "prosperous and equitable society living in harmony with our natural resources" (DEA Strategic Plan, 2009-2014:12-13). Notably, the plan underscored the importance of providing 
environmentally focused leadership and coordinating government's approach to extensive, complex and cross-sectoral issues, such as climate change and sustainable development (DEA Strategic Plan, 2009-2014).

\section{VARIABLES INFLUENCING ENVIRONMENTAL PROTECTION AND ECONOMIC DEVELOPMENT}

The term "environmental protection" outlines practices that are concerned with protecting the natural environment to help facilitate the longer-term survival of all living species. Issues relating to environmental protection include urbanisation, the pollution of water sources, over-fishing, air-quality and most notably, climate change. As a result of these movements, there is general consensus that sustainable development should be a global aim. To improve sustainable development, governments should act as catalysts, custodians and champions of environmental change. As a driving force for change, they should make resources available and establish statutory frameworks conducive to protect the environment. However, subnational governments also play a key role in economic growth, socioeconomic development and the welfare of citizens. A central issue to subnational governments' role as catalysts of socio-economic development centres on striking a healthy balance between economic development and the environment. In this sphere, rapid population and economic growth has significantly increased the demand for natural resources and infrastructure. To balance these demands, governments should regulate development initiatives to protect the environment and promote economic growth in equal measure.

According to the World Bank (2016 in Van der Waldt, 2017: 55), Africa is the poorest region of the world. The continent is home to the largest percentage of people living on less than $\$ 1$ per day. In fact, nearly $40 \%$ of all people in Africa live below the accepted daily income required to sustain themselves. About a third of Africa's population is undernourished and suffer from unabated poverty. Thirty-five out of forty-five countries on the UNDP list of low human development indicators are in Africa; of the 48 countries included in the list of least-developed countries (LDCs) two-thirds are in Africa (Van der Waldt, 2017:55).

\section{Environmental Perspectives}

Natural disasters (i.e. floods, droughts, earthquakes and landslides) cause significant damage to infrastructure. The situation is exacerbated by a general lack of environmental risk and impact assessments. Undeniably, environmental 
degradation continues to undermine the fight against poverty through economic growth and sustainable development.

Introduced by the Economic Commission of Africa (ECA), many regard the Lagos Plan of Action (LPA) as the first true representation of African self-consciousness (Adebayo, 1985:14). To gain intellectual independence from "developed" countries, LPA role-players analysed how foreign ideas and programmes influence Africa's development and took steps to ensure that the continent's governments accept the need for transformation, independence and self-reliance (Adebayo, 1985:15). In their review of economic development achievements in Africa since large-scale independence in the 196os, it was found that especially economic growth was on the decline. To this end, the ECA proposed a Revised Framework of Principles for the Implementation of the New International Order in Africa in 1976. The framework underscored four fundamental principles that were thought to lead to a more Afrocentric development approach, namely self-reliance, self-sustainment, democratising the development process and a just distribution of development benefits (Van der Waldt, 2017:57).

The LPA's main contribution was its emphasis on "collective self-reliance, selfsustaining development, and economic growth" (OAU, 1980 in Van der Waldt, 2017: 56), so that Africans could move beyond external dependence (Adebayo, 1985:13). Unfortunately, to date, Africa has not produced a well-coordinated and integrated response to issues associated with climate change and sustainable development.

According to UNECA (2015:1), the post-2015 Development Agenda on the African Continent was largely informed by the Africa Rio+20 and subsequent discussions that took place in the five sub-regions of Africa (North, Central, East, West and Southern Africa). Based on UN Resolution 64/236, Africa Rio+20 refers to the Africa Consensus Statement (20-25 October 2011), which seeks consensus among African countries to secure political commitment for sustainable development (Van der Waldt, 2017:57). It further calls for realistic operational measures and subsequent capacity to ensure that the sustainable development initiatives adopted at Rio+20 are implemented (Van der Waldt, 2017: 57). The Africa Rio+20 emanated from the Arusha Declaration on Africa's Post-Rio+2o Strategy for Sustainable Development, which was drafted at the fourteenth session of the African Ministerial Conference on the Environment that took place in Arusha, Tanzania, from 12-14 September 2012 (Van der Waldt, 2017:57). The five sub-regions of Africa all identified unique priorities relating to sustainable development. The UNECA (2015:3) highlights the following priorities per region:

- North Africa: Climate change; economic diversification; job creation; food and energy security; social equality and the availability of basic services. 
- West Africa: Access to quality education; reducing widespread poverty; access to adequate healthcare; combatting gender inequality; agrarian and nutritional security; environmental and natural resource management; social systems that protect the poor and vulnerable; access to sustainable water, energy and transport; sanitation and urban management; and developmentfocused partnerships.

- Central Africa: Diversifying the economy; developing infrastructure; alleviating poverty, hunger and malnutrition; education; finding viable solutions to unemployment and underemployment; ensuring quality water resources, sanitation and urban management; and combatting gender inequality and facilitating empowerment;

- East Africa: Facilitating economic growth; creating jobs; human development; a focus on quality, inclusive education and skills development; agricultural productivity; creating viable energy resources; access to healthcare; combatting environmental and climate change-related challenges; and developing infrastructure.

- Southern Africa: Countering poverty and inequality; a focus on health and nutrition; access to education; empowering women and countering gender inequality; sustainable environmental management and climate change (UNECA, 2015:3).

The African Development Bank (ADB) (2011) projects by 2030, the continent will have a population of 1.6 billion. In general, population growth is linked to a greater risk of, and challenges relating to, poverty, famine, disease, as well as land use, access to fresh water and other life-sustaining natural resources.

\section{Economic Development Perspectives}

Despite financial challenges in the global arena, Africa has seen significant economic growth in the last decade. The average recorded growth rate of $4 \%$ is almost double the global average, while African countries are among the fastest growing economies in the world. According to the Cato Institute's Economic Development Bulletin (in Van der Waldt, 2017: 57), the percentage of Africans living on $\$ 1.25$ per day or less dropped from $56 \%$ to $48 \%$ between 1990 and 2010, while the continent's population almost doubled in size. Should this trend continue, the poverty rate could drop to $24 \%$ by 2030 (World Bank Energy in Africa, 2013).

Despite impressive economic growth, Africa remains home to some of the lowest levels of human and social development in the world. Large segments of the population are trapped in a cycle of unemployment, poverty and social inequality. The UN's 2014 Human Development Index (HDI) gave Africa a very low score of 
0.502 (Van der Waldt, 2017: 58). In contrast, the USA scored 0.914, South America 0.74 and China 0.719 . As such, African leaders are faced with the challenge of converting steady economic growth into sustained, people-centred development (Van der Waldt, 2017:58). This requires significant investment in economic infrastructure development across all sub-sectors, such as energy, water, sanitation, transportation, and information and communication technology (ICT). A largescale systemic and structural transformation is required to move away from a dependence on natural resources. Countries should adopt an economic system that is founded on industrial development, as well as globally-competitive products and services. This shift could significantly enhance countries' resilience to global economic shocks.

\section{Agriculture and Nutrition Security Perspectives}

African countries are highly dependent on agriculture. Subsistence farming is the primary source of food and income for approximately two-thirds of the continent's population. According to the African Development Bank (AfDB) (2014), about a third of countries' gross domestic product (GDP) is derived from agricultural activities. Furthermore, this sector employs more people than any other sector in the economy (AfDB, 2014). As such, agriculture plays a key role in food security and sustainable poverty reduction.

In spite of a reliance on the agricultural sector, Africa is plagued by a multitude of challenges. Some of the most significant challenges include climate change, inadequate market access, low productivity, government bureaucracy and constraining legal and land policy frameworks (Van der Waldt, 2017:58). To become more globally competitive and to operationalise the SDGs of 2015, it is crucial that governments on the continent address these issues. More climatesmart agricultural technology and practices should be adopted to improve overall agricultural efficiency.

\section{Energy Perspectives}

In recent years, Africa has experienced significant economic and population growth. More industrial activity and more people translate into a higher demand for energy. According to the International Renewable Energy Agency (IREA) (2014), more than three-quarters of the continent is without electricity and $81 \%$ of all people depend on traditional biomass fuels (i.e. wood, charcoal, agricultural waste, dung, shrubs, straw and coal) for household use. Economic growth is thus seriously hampered by the inability to generate enough electricity. IREA (2014) estimates that people 
without access to electricity will increase to 655 million by 2030 (Africa's total population is approximately 1.5-billion people).

The World Bank's 'Energy in Africa Overview Report' (2013) highlights that East Africa has ample cost-effective resources, such as gas, geothermal energy, hydropower and promising coal reserves, to produce electricity and meet future energy demands. If managed effectively, these resources could form the economic backbone of future economic growth in East African Community (EAC) countries. The East Africa Power Master Plan (EAPMP) highlights that economies of scale come into play concerning electricity interconnection and trade within EAC countries (Van der Waldt, 2017:59). The Plan states that hydropower schemes in Uganda and Tanzania could bolster the capacity to render cost-effective electricity and cut dependency on oil imports (Van der Waldt, 2017:59).

\section{Water, Sanitation and Access to Basic Services}

Approximately $40 \%$ of the total African population do not have access to clean drinking water (Van der Waldt, 2017:59). Most countries on the continent are also off-track in meeting the MDGs' sanitation targets, with severe disparities between urban and rural areas. Water serves as a vital input to industrial development, is integral to hydropower generation, tourism, transport, agriculture, fisheries, as well as livestock production. Population growth has resulted in major water withdrawals from major rivers and natural water reservoirs, thus leading to water scarcity in the region. Access to hygienic sanitation infrastructure is crucial to address disease outbreaks, especially in rural areas (Van der Waldt, 2017: 59).

\section{Health Perspectives}

According to the World Health Organisation (WHO) (2014 in Van der Waldt, 2017: 59), health can be seen as a determining factor and outcome of sustainable development interventions. It is closely linked to other sustainable development outcomes, such as education, productivity and higher wages. According to WHO (2014 in Van der Waldt, 2017:59), approximately 90\% of all malaria cases in the world are in Africa. Countries on the continent also have to cope with high incidents of HIV/AIDS and childhood illnesses, such as polio and measles. Furthermore, African countries have to contend with high maternal and new-born mortality rates and poor healthcare infrastructure. 


\section{CONCLUSIONS}

Several meanings are ascribed to environmental protection. Due to the fact that environmental sustainability is a widely used phrase, idea and concept, it evokes different responses. Notably, in broad terms, the concept 'sustainability' emanated from growing concerns about several environmental and socio-economic issues and emphasises s an important shift towards an ecological paradigm that highlights the interrelationship between humanity and nature.

Subnational governments, as the catalysts and custodians of sustainable development, have a significant role to play. They should act as a driving force and set the pace for such change; and establish the necessary frameworks (including policies, strategies and programmes) to address sustainable development challenges per sector. Provincial managers need to comprehend the nature and scope of these initiatives in their respective provinces, so that they can design sustainable solutions to basic service provision. In turn, environmental managers require a diverse "skills and knowledge set" (i.e. regulatory, technological, human, social, ethical and political know-how) that they can call on when dealing with environmental challenges.

Therefore, it is evident that managers/leaders involved in environmental protection must also be able handle the complex nature of environmental issues;

- integrate opposing outlook/s;

- comprehend and address role-players' expectations; and

- change organisational practices.

It is crucial that subnational governments promote ownership and co-responsibility for the implementation of strategic projects and strategies. Furthermore, they should be aware of their roles and responsibilities in implementing the SDGs. Provincial plans should provide a comprehensive vision of the territory and strategies based on an integrated and multi-dimensional approach to inclusive and sustainable development. Provincial governments should proactively resist topdown approaches that reduce their role to implement priorities decided unilaterally by national government. Furthermore, they should align their Provincial Growth and Development Plans (PGDPs) and institutional frameworks with the NDP, as well as contribute to the SDGs with a consolidated political message based on their knowledge and experience to promote multi-level governance. 


\section{References}

Adebayo, A. (1985). The Monrovia Strategy and the Lagos Plan of Action: Five years after. In: Adedejl, A. and Shaw, T.M. (Eds.). Economic Crisis in Africa: African Perspectives on Development Problems and Potentials. Boulder, CO: Lynne Rienner.

African Development Bank (AfDB) (2011). African development report: "Private sector development as an engine of Africa's economic development" (online). Available at: www.afdb.org/en/knowledge/publications/african-development-report/african-development-report-2011/. Accessed 20 $0^{\text {th }}$ May 2016.

African Development Bank (AfDB) 2014. African economic outlook 2014 (online). Available at: www.afdb.org/en/knowledge/publications/african-economicoutlook/african-economic-outlook-2014/. Accessed 26 ${ }^{\text {th }}$ April 2017.

Auriacombe, C.J. (2014). Government, environment and sustainable development. UJ Internal Handbook PMG 1B. Johannesburg: University of Johannesburg, pp. 1-238.

Auriacombe, C.J. and Jarbandhan, V. (2015).The Dimensions of Environmental Leadership: Bringing together the nexus of Sustainable Development, the Environment and Leadership. Administratio Publica, 23(4), pp. 16-143.

Boiral, O., Cayer, M. and Baron, C.M. (2009). The Action Logics of Environmental Leadership: A Developmental Perspective. Journal of Business Ethics, 85(4), pp. 479-499.

Castro, C.J. (2004). Sustainable Development; Mainstream and Critical Perspectives. Organizations and Environment. 17 (online). Available at: oae.sagepub.com/ content/17/2/195. Accessed $6^{\text {th }}$ April 2017.

Cavalcanti, C. (2000). The Environment, Sustainable Development and Public Policies. Cheltenham, UK: Edward Elgar.

Chasek, P.S. and Wagner, L.M. (2012). Lessons Learned from Twenty Years of Multilateral Environmental Negotiations. New York: Taylor and Francis.

DEA (2011). Department of Environmental Affairs. National Strategy for Sustainable Development and Action Plan (NSSD1) 2011-2014. Pretoria: Department of Environmental Affairs.

Department of Environmental Affairs (Undated). National Climate Change Response: White Paper 2014 (online). Available at: www.environment.gov.za/climate. Accessed $16^{\text {th }}$ May 2015. 
Department of Environmental Affairs (2013). Strategic Plan 2009-2014 (online). Available at: www.environment.gov/za/climate change. Accessed $4^{\text {th }}$ December 2013.

Green Economy (2017). Implementation Plans (online). Available at: www. enviropaedia.com/topic/default.php?topic_id=342. Accessed 23 ${ }^{\text {rd }}$ May 2017.

Haque, M.S. (1999). The Fate of Sustainable Development Under Neo-Liberal Regimes in Developing Countires. International Political Science Review, 20:197 (online). Available at: ips.sagepub.com/content/20/2/197. Accessed $4^{\text {th }}$ April 2017.

Hopwood, B. Mellor, M. and O’Brien, G. (2005). Sustainable Development: Mapping Different Approaches. ERP Journal, 13 (1), pp.38-52.

International Renewable Energy Agency (IREA) (2014). REmap 2030 Report (online). Available at: www.irena.org/remap. Accessed $3^{\text {rd }}$ March 2016.

Johannesburg Plan of Implementation (JPOI) (2002) (online). Available at: www. uncsd2012.org/content/documents/814UNCSD\%20REPORT\%20final\%2orevs. pdf. Accessed $3^{\text {rd }}$ May 2016.

Kumar, N., Harris, J. and Rawatif, R. (2015). They Grow It, Will They Eat and Grow? Evidence from Zambia on Agricultural Diversity and Child Undernutrition. The Journal of Development Studies. 51 (8), pp. 1060-1077.

Lele, S.M. (1991). Sustainable Development: A Critical Review. World Development, 19(6), pp. 607-621.

National Planning Commission (NPC) (2011). National Development Plan. Vision for 2030. (November). NPC (online). Available at: www.npconline.co.za. Accessed $1^{\text {st }}$ December 2012.

National Planning Commission (NPC) (2009). Together Doing More and Better. Medium Term Strategic Framework. A Framework to Guide government's Programme in the Electoral Mandate Period (2009 - 2014). Pretoria: The Presidency of the Republic of South Africa.

National Climate Change Response (2011) White Paper, 2011. Pretoria: Government Printers (online). Available at: rava.qsens.net/themes/theme emissions/111012nccr-whitepaper.pdf. Accessed $8^{\text {th }}$ December 2016.

NFSD (2007). People - Plane - Prosperity: A Strategic Framework for Sustainable Development in South Africa. Draft for Comment. Department of Environmental Affairs and Tourism. 2007. Pretoria: Government Printers.

National Framework for Sustainable Development (NFSD) (2008). National Framework (online). Available at: www.environment.gov.za/sites/default/ 
files/docs/2008nationalframeworkfor_sustainabledevelopment.pdf. Accessed $3^{\text {rd }}$ May 2016.

Republic of South Africa (1996). The Constitution of the Republic of South Africa, 1996. Pretoria: Government Printers.

Republic of South Africa (1998). National Environment Management Act 107 of 1998 (NEMA). Pretoria: Government Printer.

Roadmap for Localizing the SDGs: Implementation and Monitoring at Subnational Level. (Undated) (online).Availableat:sustainabledevelopment.un.org/.../818_11195_ committment-ROADMAP\%20I.pdf. Accessed ${ }^{\text {rd }}$ September 2018.

Sachs, J. (2012). From Millennium Development Goals to Sustainable Development Goals. Lancet, 379, pp. 2206 - 2211.

Saunders, H.D. (2014). Toward a neoclassical theory of sustainable consumption: Eight golden age prepositions. Ecological Economics. 105, pp. 220 - 232.

United Nations (1992). Implementation of Agenda 21: Review of progress made since the United Nations Conference on Environment and Development. Information provided by the Government of South Africa to the United Nations Commission on Sustainable Development. Fifth session. 7-25 April 1997: New York: United Nations.

United Nations (1992a). Agenda 21: Programme of action for sustainable development. New York: United Nations.

United Nations Development Programme (UNDP) (1997). Governance for Sustainable Human Development. New York, NY: UNDP.

United Nations General Assembly (2012). The future we want (online). Available at: www.un.org. Accessed 22 $2^{\text {nd }}$ May 2017.

United Nations Economic Commission for Africa (UNECA) (2003). Sustainable development indicators (online). Available at: wwwl.uneca.org/. Accessed $20^{\text {th }}$ February 2018.

United Nations Economic Commission for Africa (UNECA) (2015) (online). Available at: www.uneca.org/. Accessed $14^{\text {th }}$ March 2016.

UN Habitat (2012). Roadmap for Localising the SDGs: Implementation and Monitoring at Subnational Level (Online). Available at: https://unhabitat.org/roadmapfor-localizing-the-sdgs-implementation-and-monitoring-at-subnationallevel/. Accessed $25^{\text {th }}$ May 2018. 
United Nations Human Development Report Office (UN-HDRO) (2015). Human development index (HDI) (online). Available at: hdr.undp.org/en/content/ human-development-index-hdi. Accessed $26^{\text {th }}$ April 2017.

Van der Waldt, G. (2017). Africa and Sustainability: Governance Functions and Applications.

UJ Internal Handbook - Learning Material Section A. Johannesburg: University of Johannesburg.

Van der Waldt, G. and Auriacombe, C.J. (2014). PMG1A: Internal Handbook: Section A: Government, environment and sustainable development. Johannesburg: University of Johannesburg.

Willis, K. (2005). Theories and Practices of Development. London: Routledge.

World Bank (2007). World Development Report 2007: Development and the Next Generation. Washington, D.C.: World Bank (online). Available at: documents. worldbank.org. Accessed $22^{\text {nd }}$ June 2017.

World Bank (2013). Energy in Africa (online). Available at: web. worldbank.org/WBSITE/EXTERNAL/COUNTRIES/AFRICAEXT/o, ,contentMDK:21935594 pagePK:146736 piPK:146830 theSitePK:258644,oo. html. Accessed 23 ${ }^{\text {rd }}$ April 2017.

World Bank (2016). Poverty overview (online). Available at: www.worldbank.org/en/ topic/ poverty/overview. Accessed 23 $3^{\text {rd }}$ April 2018.

World Bank (2013). Energy in Africa (online). Available at: web. worldbank.org/WBSITE/EXTERNAL/COUNTRIES/AFRICAEXT/o, ,contentMDK:21935594 pagePK:146736 piPK:146830 theSitePK:258644,oo. html. Accessed 23 ${ }^{\text {rd }}$ March 2018. 